\title{
Effect of Dehydration on Several Physico-Chemical Properties and the Antioxidant Activity of Leeks (Allium porrum L.)
}

\author{
Mehmet OZGUR', Arzu AKPINAR-BAYIZIT², Tulay OZCAN², Lutfiye YILMAZ-ERSAN² \\ ${ }^{1}$ Uludag University, Faculty of Agriculture, Department of Horticulture, Gorukle Campus, Bursa, 16059, Turkey; mozgur@uludag.edu.tr \\ ${ }^{2}$ Uludag University, Faculty of Agriculture, Department of Food Engineering, Gorukle Campus, Bursa, \\ 16059,Turkey; abayizit@uludag.edu.tr, tulayozcan@uludag.edu.tr,lutfiyey@uludag.edu.tr
}

\begin{abstract}
This study investigated the changes in some physico-chemical properties and variations in antioxidant compounds of leeks (cv. 'Inegol-92') caused by the drying process. The dry matter and ash contents of the fresh leek samples were 8.06 and $0.58 \mathrm{~g} 100 \mathrm{~g}^{-1}$, respectively. The $\mathrm{pH}$ of the fresh leek samples was 6.02 , and the titritable acidity in terms of citric acid was $0.14 \%$. As expected, application of hot-air drying significantly increased the dry matter and ash values due to removal of water from the leek slices. The rehydration ratio of dried leeks at $45^{\circ} \mathrm{C}$ was 5.41 , and the coefficient of rehydration was 0.47 . The contents of chlorophyll $a$ and $b$ were higher in the dried leeks than in the fresh leeks. The dehydrated leeks showed a high total color difference $(\Delta E=12.53)$ mainly due to the effect of temperature on heat-sensitive compounds. As expected, both fresh and dried leek samples exhibited antioxidant activity with fresh leeks showing a higher capacity of antioxidant activity. Drying the leeks resulted in some ascorbic acid loss. Fresh leeks had much higher phenolic values ( $26.33 \mathrm{mg}$ rutin eq $100 \mathrm{~g} \mathrm{DM}^{-1}$ ) than the dehydrated samples. The antioxidant capacity of leeks was decreased by more than $50 \%$ during the drying process. Although being the most applied method of thermal dehydration, hot air drying causes the degradation of sensitive components, which results in significant losses in sensorial and physico-chemical properties of the dried products.
\end{abstract}

Keywords: antioxidant activity, carotenoids, drying, leek, phenolic compounds

\section{Introduction}

Fruits and vegetables have an important role in human nutrition because they contain constituents that have health benefits and anti-disease factors, such as antioxidants and polyphenols. These components are known to scavenge harmful free radicals that are associated with incidence of cancer and heart diseases (Cao et al., 1996; Velioglu et al., 1998).

Leeks (Allium porrum L.) are the most commercially produced vegetables in the world. Along with onions and garlic, leeks belong to the Allium genus (family Alliaceae). Indonesia is the largest producer of leeks in the world, followed by Turkey, France and Belgium. In 2009, leek production in Turkey was 320,000 metric tons, and leeks are the second most exported dried product after tomatoes with 116,000 metric tons (Anonymous, 2008). Fresh leeks are a good source of nitrates, flavonoids, polysaccharides and glucosinolates in addition to numerous organosulfur components contributing to their rich flavor (Ferary and Auger, 1996; Mondy et al., 2002; Lanzotti, 2006). Epidemiological and laboratory studies have suggested that Allium vegetables have tumor-inhibitory properties. The consumption of leeks reduces risk of prostate, colorectal, stomach and breast cancer (Bianchini and Vainio, 2001; Hsing et al., 2002). The anti-carcinogenic action may be related to the high content of organosulfur compounds and other biophenols with high antioxidant activity (Steinmetz and Potter, 1996; Fattorusso et al., 2001; Galeone et al., 2006). These bioactive compounds also have antifungal activity (Vergawen et al., 1998; Yin and Tsao, 1999) and inhibitory activity on human platelet aggregation, which can prevent atherosclerosis (Fattorusso et al., 2001). Similar to other agricultural products, leeks are perishable and must either be consumed rapidly or preserved by various methods, such as drying, freezing or cold storage (Magra et al., 2006; Tsouvaltzis et al., 2006). The process of drying is one the oldest methods for food preservation, and drying is a complex process involving heat and mass transfer phenomena, which occurs frequently in most of the food processing industries (Cohen and Yang, 1995; Vega-Gálvez et al., 2009).

Drying brings substantial reduction in weight and volume, which minimizes packaging, storage and transportation costs (Okos et al., 1992; Sobukola et al., 2007). Moreover, products with a low moisture content can be stored at ambient temperatures for longer periods of time due to a considerable decrease in the water activity of the material, reduced microbiological activity and minimized physical and chemical changes (Araujo et al., 2004; VegaGálvez et al., 2007). However, food products are sensitive to drying temperature, which can induce degradation (e.g. oxidation, loss of color, shrinkage or loss of texture) and nutritional/functional properties (Attanasio et al., 2004; 
Luangmalawat et al., 2008). Therefore, the key factor in successful drying of vegetables depends on the application of heat to lower the moisture content as quickly as possible at a temperature that does not seriously alter the flavor, texture and color of the product. Furthermore, circulation of dry air to absorb and carry off the released moisture is also important for a successful drying.

Several types of dryers and drying methods are commercially used to remove moisture from a wide variety of vegetables. There are three basic types of drying processes as follows: i) sun and solar drying; ii) batch and continuous atmospheric drying; and iii) subatmospheric dehydration. The selection of a particular dryer/drying method depends on the type of raw material, properties of the raw material, desired characteristics of the dried product, restrictions on the operating conditions and cost (Raghavan and Orsat, 2007). Natural sun drying is a slow process when compared to other drying methods, and quality losses are observed mainly in color degradation, microbial growth and poor rehydration (Latapi and Barrett, 2006).

Dried vegetables are more concentrated than any other preserved form of foodstuffs and are tasty, nutritious, lightweight and easy to prepare, store and use (Senadeera et al., 2000). However, the drying process may lead to changes in physico-chemical and functional components. Therefore, the main objectives of this study were to determine the effect of hot air drying on the antioxidant activity and total phenolic content of leeks.

\section{Materials and methods}

\section{Leek samples}

Fresh and dried leek (Allium porrum L., cv. 'Inegol-92') samples were obtained from a commercial company processing dried vegetables in Bursa. The fresh leek samples were washed in tap water, and all inedible parts were removed manually or using a steel knife. Bruised or wounded leeks were discarded.

For the dehydration process, leeks were cut into slices $(1 \mathrm{~cm} \times 1 \mathrm{~cm} ; \pm 0.1 \mathrm{~cm})$ with a cutting machine and placed on stainless steel trays in a forced-air drier in a commercial dehydration plant. The leeks were dried at a temperature of $63^{\circ} \mathrm{C} \pm 2^{\circ} \mathrm{C}$ for $3 \mathrm{~h}$ with an air velocity of $2.5 \mathrm{~m} / \mathrm{s}$. The dried leeks were immediately packed in airtight, resealable polyethylene bags and stored at $25^{\circ} \mathrm{C} \pm 1^{\circ} \mathrm{C}$. Each experiment was carried out in triplicate.

\section{Chemicals and reagents}

All chemicals and reagents used were of analytical quality grade. All samples and standard preparations were performed under subdued light. Contact with air was avoided as much as possible, and most experiments were carried out under a nitrogen atmosphere. Ascorbic acid and lycopene were purchased from Sigma-Aldrich (St. Louis, MO, USA). Gallic acid was purchased from CQA Quimica (Campinas, SP, Brazil). All other reagents, including
Folin-Ciocalteu reagent, potassium hydroxide, ethanol absolute, methanol, tetrahydrofuran, hexane, acetone, petroleum ether $\left(40\right.$ to $\left.65^{\circ} \mathrm{C}\right)$, di-tert-butyl-methylphenol (BHT), sodium chloride and magnesium carbonate, were purchased from Merck (Darmstadt, Germany).

\section{Physico-chemical analysis}

For each physico-chemical analysis, at least $300 \mathrm{~g}$ of fresh leeks was chopped in a domestic chopper (model K 1191, Arcelik Inc., Turkiye), obtaining a homogenized leek extract that was used in all analyses and stored at $-20^{\circ} \mathrm{C}$ until analysis. Three independent samples were prepared, and each sample was analyzed in triplicate.

Rehydration experiments were carried out in distilled water at $45^{\circ} \mathrm{C}$. Dried leek samples $(10 \mathrm{~g})$ were added to $100 \mathrm{ml}$ of water and mixed thoroughly. The samples were allowed to rehydrate for $5 \mathrm{~h}$, and the rehydration temperature was kept constant using a water bath with adjustable temperature control. At the end of the rehydration period, the water was drained, and the weight and moisture content were determined. The rehydration ratio was expressed as a ratio of water absorbed by the dried sample $\left(\mathrm{W}_{\mathrm{r}}\right)$ to the weight of the dried sample $\left(\mathrm{W}_{\mathrm{d}}\right)$ (rehydration ratio, $\left.\mathrm{R}_{\mathrm{r}}\right)$ (Eq. 1). The coefficient of rehydration (CR) representing water absorption during rehydration was determined as suggested by Rangana (1986) (Eq. 2). The following equations were used to calculate the rehydration ratio and coefficient of rehydration:

$$
\begin{aligned}
& R_{r}=W_{r} / W_{d} \\
& C R=\frac{D_{w t} x(100-A)}{\left(W_{d}-B\right) \times 100}
\end{aligned}
$$

where $\mathrm{D}_{\mathrm{wt}}$ is the drained weight of rehydrated sample; $\mathrm{A}$ is the moisture of sample before drying (\% wet basis); $\mathrm{W}_{\mathrm{d}}$ is the weight of dried sample; and $\mathrm{B}$ is the moisture present in the dried sample taken for rehydration (\% wet basis).

Contents of moisture, ash, $\mathrm{pH}$ and titritable acidity (expressed as \% citric acid) were measured according to the Association of Office Analytical Chemists (AOAC, 2000). Dried leeks were analyzed after rehydrating at $25^{\circ} \mathrm{C}$ for $3 \mathrm{~h}$.

The CIELAB coordinates, including $L^{*}$ (color lightness), $a^{*}$ (position on the green/red axis; blue/green and $\mathrm{red} /$ purple hue component), and $b^{*}$ (position on the blue/ yellow axis; yellow/blue hue component), were measured on randomly selected locations of fresh (along the white to green cut) and dried leeks (where the white and green cuts are mixed) using a Minolta Chromameter CR-300 (Minolta Camera Co. Ltd., Osaka, Japan). The chromameter consisted of a measuring area of $8 \mathrm{~mm}$ in diameter, and diffuse illumination $/ 0^{\circ}$ viewing was used. The measurements were taken with a pulsed xenon lamp. Color changes in 
146

the leek samples due to drying were evaluated through the total color difference ( $\Delta E$; Eq. 3 ) parameter as follows:

$$
\operatorname{TCD}(\Delta E)=\sqrt{(\Delta L)^{2}+(\Delta a)^{2}+(\Delta b)^{2}}
$$

where $\Delta L$ is the difference of lightness $\left(\mathrm{L}-\mathrm{L}_{0}\right) ; \Delta a$ is the difference of redness $\left(\mathrm{a}-\mathrm{a}_{0}\right)$; and $\Delta b$ is the difference of yellowness $\left(b-b_{0}\right)$.

\section{Quantitative analysis of chlorophyll a and $b$ in leeks}

Fresh and dried leek samples ( $3 \mathrm{~g}$ ) were homogenized with quartz sand, and 20 to $25 \mathrm{ml}$ of $85 \%$ acetone was added followed by additional homogenization. The homogenate was then filtered into a $100 \mathrm{ml}$ volumetric flask. The residue was washed with acetone approximately three times until the extract was clear, and $85 \%$ acetone was added to a final volume of $100 \mathrm{ml}$. The samples were kept in the dark until spectrometric analyses. The absorbance of the extract was measured at $663,645,652$ and $750 \mathrm{~nm}$ (reference=acetone). The $\mathrm{E}_{750}$ value was subtracted from the $\mathrm{E}_{663}$ (chlorophyll $a$ ), $\mathrm{E}_{645}$ (chlorophyll $b$ ) and $\mathrm{E}_{652}$ (total chlorophyll) values. The corrected values were used for the determination of chlorophyll $a$, chlorophyll $b$ and total chlorophyll concentrations in the leeks (Wellburn, 1994; Butz et al., 2002).

\section{Quantitative analysis of antioxidant compounds}

\section{L-Ascorbic acid}

Ascorbic acid content was determined using the 2,6dichlorophenol-indophenol (0.0012\%) method at 520 $\mathrm{nm}$ described by the Association of Official Analytical Chemists (AOAC, 1996). $L$-ascorbic acid was used to prepare a standard solution $\left(1 \mathrm{mg} \mathrm{ml}^{-1}\right)$. The ascorbic acid concentration was calculated by comparison with the standard and expressed as $\mathrm{mg} 100 \mathrm{~g} \mathrm{mass}^{-1}$.

\section{Totalphenols}

Determination of total phenolic content was based on the method described by Spanos and Wrolstad (1990) with some modifications. Briefly, $150 \mu \mathrm{l}$ of extract, $2400 \mu \mathrm{l}$ of nanopure water, and $150 \mu \mathrm{l}$ of $0.25 \mathrm{~N}$ Folin-Ciocalteu reagent were combined in a plastic vial and mixed well using a vortex. The mixture was allowed to react for $5 \mathrm{~min}$ followed by the addition of $300 \mu \mathrm{l}$ of a saturated $\mathrm{Na}_{2} \mathrm{CO}_{3}$ $(1 \mathrm{~N})$ solution. Distilled water was added to a final volume of $10 \mathrm{ml}$, and the samples were mixed thoroughly. The solution was incubated at room temperature $\left(23^{\circ} \mathrm{C}\right)$ in the dark for $2 \mathrm{~h}$. The absorbance readings of the reaction mixtures were measured at $725 \mathrm{~nm}$ using a spectrophotometer (Hewlett Packard 8452A, Diode Array, USA) against a blank. The results were expressed in Gallic acid equivalents (GAE; mg $100 \mathrm{~g}$ fresh mass $^{-1}$ ) using a Gallic acid (GA) standard curve $\left(0-0.1 \mathrm{mg} \mathrm{m}^{-1}\right)$. The results were expressed as milligram GAE per gram of fresh weight. Additional di- lutions were carried out if the measured absorbance value was greater than the linear range of the standard curve.

\section{Lycopene content}

The extraction and detection of lycopene was carried out by a modified method described by Heinonen $e t$ al. (1989) and Konings and Roomans (1997). Fresh leeks were homogenized in a blender. Aliquots of sample homogenates $(1.5$ or $5 \mathrm{~g})$ were weighed into a $250 \mathrm{ml}$ separation funnel. Lycopene was extracted with methanol/tetrahydrofuran (THF) $(1: 1 ; \mathrm{v} / \mathrm{v})$ using $\mathrm{Na}_{2} \mathrm{SO}_{4}$ and $\mathrm{MgCO}_{3}$ as desiccants until colorless. The samples were extracted at least two or three times to remove all of the lycopene from the leeks. Supernatants were collected in $500 \mathrm{ml}$ stoppered conical flasks. The concentrate was saponified at room temperature for $2 \mathrm{~h}$ in the dark with $12.5 \mathrm{ml}$ of potassium hydroxide $(50 \% \mathrm{KOH}$ solution) in a mixture of petroleum ether $(50 \mathrm{ml})$ and water $(20 \mathrm{ml})$ until the petroleum ether phase was colorless. Before solvent extraction, the saponification extract was diluted with a solution of sodium chloride $\left(10 \%\right.$ in $\mathrm{H}_{2} \mathrm{O}$; w/v). After addition of $\mathrm{NaCl}$, unsaponified and saponified solutions were extracted with $50 \mathrm{ml}$ of petroleum ether. From the saponified samples, combined petroleum ether portions were washed with $100 \mathrm{ml}$ portions of water until the reaction $\mathrm{pH}$ was neutral. Organic layers were evaporated to dryness. The residue was dissolved by ultrasonic agitation in methanol/THF $(1: 1 ; \mathrm{v} / \mathrm{v})$ with BHT as the antioxidant, and the sample was then filtered through a $0.45 \mu \mathrm{m}$ filter. For dried samples, the extraction and preparation of lycopene was carried out after rehydration of the dried samples at $45^{\circ} \mathrm{C}$ for $5 \mathrm{~h}$. Both extracts of fresh and dried leeks were analyzed with the nonaqueous reversed-phase (NARP) HPLC system (Varian Vista 5500 liquid chromatographs, Varian) equipped with Varian UV-200 detectors and Varian 4270 integrators. In the NARP chromatography, the Zorbax ODS column ( $5 \mu \mathrm{m}, 250 \mathrm{~mm}$ x $4.6 \mathrm{~mm}$; i.d.; DuPont) was preceded by a guard column $(5 \mathrm{cmx} 0.46 \mathrm{~cm}$; i.d.) packed with Bondapak AX/Corasil $(37-50 \mathrm{pm})$ (Waters). The elution mixture was a mixture of methanol and THF (95:5; $/ \mathrm{v})$, and the flow rate was $0.8 \mathrm{ml} \mathrm{min}^{-1}$. Lycopene was detected at $450 \mathrm{~nm}$, and the columns were run at $30^{\circ} \mathrm{C}$. Approximately $20 \mu \mathrm{l}$ of both standards and samples were injected into the system. The separated peaks were recorded, and the peak areas were determined. The lycopene concentrations in the samples were identified by comparing their retention times with those of authentic standards.

\section{Total antioxidant capacity (FRAP assay)}

The ferric reducing antioxidant power (FRAP) assay was done according to the method adapted from Benzie and Strain (1999). The working FRAP reagent was freshly prepared as follows: $2.5 \mathrm{ml}$ of a $10 \mathrm{mM} \mathrm{2,4,6-trispyridyl}$ triazine (TPTZ) solution in $40 \mathrm{mM} \mathrm{HCl} 2.5 \mathrm{ml}$ of 20 $\mathrm{mM}$ ferric chloride and $25 \mathrm{ml}$ of $0.25 \mathrm{M}$ acetate buffer 
( $\mathrm{pH}$ 3.6). An aliquot ( $150 \mu \mathrm{l})$ of the sample was added to $300 \mu \mathrm{l}$ of distilled water and allowed to react with $2.85 \mathrm{ml}$ of the FRAP solution for $30 \mathrm{~min}$ in the dark followed by the addition of $3 \mathrm{ml}$ of the FRAP reagent. Readings of the colored product (ferrous tripyridyltriazine complex) were then taken at $593 \mathrm{~nm}$ against a blank. The standard curve was constructed using ferrous sulfate standard solutions over the linearity range of 0.2 to $1.0 \mathrm{mmol} \mathrm{l}^{-1}$. The antioxidant activities of the samples were determined from the standard curve of ferrous sulfate using their measured absorbance values. The results were expressed in mmol $\mathrm{I}^{-1}$. Additional dilutions were carried out if the measured FRAP value was greater than the linear range of the standard curve.

\section{Statistical analysis}

Results were expressed as mean values \pm standard deviations. Each analysis assay was done three times from the same sample to determine reproducibility. Analysis of variance (ANOVA) was used to test any difference in properties of fresh and dried leek samples. Duncan's new multiple range test was used to determine significant differences. Correlations among data obtained were calculated using Pearson's correlation coefficient $(r)$.

\section{Results and discussion}

\section{Physico-chemical analysis}

The dry matter and ash contents of fresh leek samples

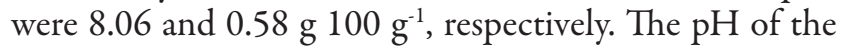
fresh leek samples was 6.02, and the titritable acidity in terms of citric acid was $0.14 \%$ (Tab. 1.). As expected, application of hot air drying significantly increased the dry matter and ash values due to removal of water from the leek slices. The titritable acidity of the leeks was significantly increased by the drying process, whereas the $\mathrm{pH}$ values were decreased. The method of drying is one of the important factors affecting the final quality of food products. Although being the most applied method of thermal dehydration, hot air drying causes the degradation of sensitive components, which results in significant losses of sensorial and physico-chemical properties of the dried products.
The rehydration ratio of the dried leeks at $45^{\circ} \mathrm{C}$ was 5.41, and the coefficient of rehydration was calculated as 0.47 . There are two processes during rehydration as follows: absorption of water and leaching of solutes. An observed increase in mass is a net result of the two rehydration processes. Assuming that perfect rehydration yields a product with similar proximate composition of the raw material, rapid and complete rehydration is an essential quality parameter of any dried product. Singh et al. (2006) and Doymaz (2008) examined the effect of water temperature on rehydration capacity, and they stated that rehydration capacity at a high rehydration temperature is improved due to the interaction between temperature and cell walls or tissues. Taiwo et al. (2002) reported that water uptake of dried apple slices is higher at rehydration temperatures greater than $90^{\circ} \mathrm{C}$, which promote faster diffusion of water into the product through the swelling and plasticizing of cell membranes.

\section{Color changes}

Color, an important attribute in food products, can be assessed either by a sensory panel or using analytical instrumentation, and it is the quality parameter immediately perceived by the consumer. Color can also be a measurement of reaction extensions in food products since formed and/or degraded compounds may contribute to a specific coloration. The ANOVA analysis indicated significant differences $(p<0.05)$ in the color characteristics between the dehydrated and fresh leeks (Tab. 2.).

The total chlorophyll content was $156.05 \mathrm{mg} \mathrm{kg}^{-1}$ in the dried leeks and $90.81 \mathrm{mg} \mathrm{kg}^{-1}$ in the fresh samples. The chlorophyll $a$ and $b$ contents were higher in the dried leeks when compared to the fresh leeks mainly in accordance with the increase in dry matter.

The changes in the $L^{*}, a^{*}$ and $b^{*}$ values were significant in the dehydrated leeks. The behavior of the $L^{*}$ coordinate, which represents lightness, was 66.95 in the fresh leeks and 60.57 in the dried leeks. There was a clear darkening of dried leeks, which was demonstrated by a decrease in the $\mathrm{L} / \mathrm{L}_{0}$ value. Hot air drying resulted in a decreased $L^{*}$ value $(\Delta L=6.38)$ and an increased $a^{*}$ value $(\Delta a=-10.65)$ for the dried samples as compared with the fresh samples. However, the $b^{*}$ value $(\Delta b=1.71)$ of the dried samples was

Tab. 1. Proximate composition of fresh and dried leek samples (means; $n=2$ )

\begin{tabular}{|c|c|c|c|c|c|c|}
\hline Sample & $\begin{array}{l}\text { Dry matter } \\
\left({\left.\mathrm{g} 100 \mathrm{~g}^{-1}\right)}\right.\end{array}$ & $\begin{array}{c}\text { Ash } \\
\left(\mathrm{g} 100 \mathrm{~g}^{-1}\right) \\
\end{array}$ & $\mathrm{pH}$ & $\begin{array}{c}\text { Titritable } \\
\text { acidity }(\%)\end{array}$ & $\begin{array}{c}\text { Rehydration ratio } \\
\left(\mathrm{R}_{r}\right)\end{array}$ & $\begin{array}{c}\text { Rehydration } \\
\text { coefficient }\left(\mathrm{R}_{c f}\right)\end{array}$ \\
\hline Fresh & $8.06 \pm 0.26$ & $0.58 \pm 0.15$ & $6.02 \pm 0.01$ & $0.14 \pm 0.01$ & ...- & $\ldots$ \\
\hline Dried & $92.86 \pm 0.38$ & $6.29 \pm 0.10$ & $5.02 \pm 1.71$ & $1.60 \pm 0.00$ & 5.41 & 0.47 \\
\hline
\end{tabular}

Tab. 2. Color characteristics of fresh and dried leek samples (means; $n=2$ )

\begin{tabular}{|c|c|c|c|c|c|c|c|}
\hline \multirow{2}{*}{ Sample } & \multicolumn{3}{|c|}{ Chlorophyll $\left(\mathrm{mg} \mathrm{kg}^{-1}\right)$} & \multicolumn{4}{|c|}{ Chromaticity values } \\
\hline & $a$ & $b$ & Total & $L^{*}$ & $a^{*}$ & $b^{*}$ & $\Delta E$ \\
\hline Fresh & $36.23 \pm 5.82$ & $40.78 \pm 4.65$ & $90.81 \pm 10.33$ & $66.95 \pm 2.81$ & $-14.84 \pm 3.94$ & $29.24 \pm 6.93$ & +-.-- \\
\hline Dried & $79.73 \pm 5.94$ & $54.16 \pm 2.19$ & $156.05 \pm 9.26$ & $60.57 \pm 3.20$ & $4.19 \pm 0.76$ & $27.53 \pm 2.71$ & 12.53 \\
\hline
\end{tabular}


Tab. 3. Changes in antioxidant components of fresh and dried leek samples (means; $n=2$ )

\begin{tabular}{|c|c|c|c|c|}
\hline Sample & 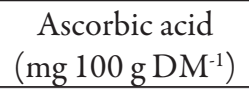 & $\begin{array}{c}\text { Total phenols } \\
\left(\mathrm{mg}^{2} \text { rutin eq } 100 \mathrm{~g} \mathrm{DM}^{-1}\right)\end{array}$ & $\begin{array}{l}\text { Lycopene } \\
\left(\mathrm{mg} \mathrm{kg}^{-1}\right)\end{array}$ & $\begin{array}{l}\text { Total antioxidant capacity } \\
\left(\mu \text { mole TEAC } 100 \mathrm{~g} \mathrm{DM}^{-1}\right)\end{array}$ \\
\hline Fresh & $7.75 \pm 1.03$ & $116.43 \pm 2.30$ & 2.66 & $223.29 \pm 24.59$ \\
\hline Dried & $12.85 \pm 2.77$ & $26.33 \pm 1.35$ & 2.77 & $95.57 \pm 1.06$ \\
\hline
\end{tabular}

similar to the $b^{*}$ value of the fresh samples. The overview of the color changes in the samples was observed by the total color variation value $(\Delta E)$. As expected, the dehydrated leeks showed a high $\Delta E$ (12.53) mainly due to the effect of temperature on heat-sensitive compounds, such as carbohydrates, proteins, and vitamins, which cause color degradation in fresh foods in addition to browning reactions and pigment destruction with drying processes (Maskan $e t$ al., 2002; Hawlader et al., 2006). Similar observations have been reported by Prothon et al. (2001) for apples, Di Scala and Crapiste (2008) for red peppers, Koca et al. (2007) for carrots, Vega-Gálvez et al. (2008) for red peppers.

\section{Antioxidant compounds and total antioxidant capacity}

As shown in Tab. 3., both fresh and dried leek samples exhibited antioxidant activity. As expected, fresh leeks had higher antioxidant capacity than the dehydrated samples. Ascorbic acid and phenolic compounds are the main contributors to the hydrophilic antioxidant activity of vegetables (Toor et al., 2005). Decreases in both total phenolics and ascorbic acid during processing are likely to be responsible for the observed decreases in the antioxidant activity in the dried leeks.

Tab. 3 shows the amount of ascorbic acid in the dehydrated and fresh leek samples. Ascorbic acid content (12.85 mg $100 \mathrm{~g} \mathrm{DM}^{-1}$ ) was found higher in the dried

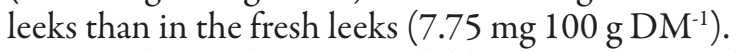

Ascorbic acid, a water-soluble vitamin, is rapidly synthesized from carbohydrates, and variations in ascorbic acid contents occur due to the different species of plants, ripeness, place of origin, storage conditions, processing and handling (Moser and Bendich, 1991; Ottaway, 1993). As expected, the hot air drying had a statistically significant influence on the ascorbic acid contents in the leeks. The change of ascorbic acid was expressed as percentage of retention. Drying the leeks resulted in some ascorbic acid loss as compared to the fresh leeks. The ascorbic acid retention was $60 \%$ for hot-air drying. It is difficult to retain ascorbic acid during the dehydration of foods because ascorbic acid is susceptible to heat (Erdman and Klein, 1982; Takeoka et al., 2001; Dewanto et al., 2002). In general, increased levels of ascorbic acid degradation result from slow drying methods (Nindo et al., 2003). The loss of ascorbic acid is dependent on many factors including the presence and type of heavy metals, such as copper and iron, in addition to light, $\mathrm{pH}$, water activity level in the product, dissolved oxygen and drying temperature (Ottaway, 1993; Villota and Hawkes, 1992). The loss of vitamin C, which is a thermo-sensitive compound, is likely due to the ele- vated processing temperature (Hawlader et al., 2006; Di Scala and Crapiste, 2008; Vega-Gálvez et al., 2008; Sigge et al., 2001) and exposure period to heat (Jayaraman and Gupta, 1995; Maharaj and Sankat, 1996).

As in Tab. 3, the fresh leeks had higher phenolic contents (116.43 mg rutin eq. $100 \mathrm{~g} \mathrm{DM}^{-1}$ ) when compared to the dehydrated samples $(26.33 \mathrm{mg}$ rutin eq $\left.100 \mathrm{~g} \mathrm{DM}^{-1}\right)$, which may be due to the breakdown of phenolics during dehydration (Crozier et al., 1997). Meyer $e$ al. (1998) stated that the antioxidant activities of phenolics in different vegetables markedly vary and that it may be due to the differences in the phenolic compound structures primarily related to their hydroxylation and methylation patterns.

The HPLC analysis in this study indicated that there was no significant difference in lycopene quantities between dehydrated leeks and fresh leeks. Dehydrated samples contained similar lycopene values as fresh leeks with values of 2.77 and $2.66 \mathrm{mg} \mathrm{kg}^{-1}$, respectively. Previous studies have stated that longer drying times and higher temperatures result in comparable losses in color and contents of bioactive compounds. Zanoni et al. (1999) reported that the presence of both light and oxygen leads to a significant loss of lycopene during the processing of tomatoes. Oxygen permeability, light exposure, and presence of some metals in the processing system favor the isomerization and oxidation of lycopene during dehydration (Shi et al., 1999). Dewanto et al. (2002) stated that an increase in the extractable lycopene content in processed products when compared to fresh tomatoes is likely caused by lycopene being mostly attached to the skins and insoluble fiber portions of the tomatoes and that heat processing may cause an increased release of lycopene from the cell matrix.

As for the antioxidant activity measured with the FRAP method, the antioxidant activity as higher in the dried leeks than in the fresh samples (Tab. 3.). The antioxidant capacity decreased by more than $50 \%$ during the drying process of the leeks; this has also been observed by Kevers et al. (2007). While heat applied during the dehydration process is the main cause of the depletion of antioxidant compounds, heat can also induce the formation of compounds, such as melanoidins in the Maillard reaction, which can contribute to the antioxidant activity (Nicoli et al., 1997; Anese et al., 1999). Vegetables contain other antioxidants in addition to phenolic compounds and ascorbic acid, such as proteins, $\beta$-carotene, $\alpha$-tocopherol, and lycopene, which may have a role in the increase of the total antioxidant activity. Moreover, heat application can increase the level of free flavonols with the antioxidant ef- 
fect (Stewart et al., 2000). Especially in the case of lycopene, recent studies have shown the potential antioxidant activity of this compound. Lycopene can almost prevent oxidative damage to DNA and liver necrosis in rats (Matos et al., 2001), and it can reduce the risk of prostate cancer (Giovannucci et al., 2002).

\section{Conclusions}

This study showed that hot air-dried leeks retained their antioxidant activity. Hot air drying also resulted in the degradation of heat-sensitive components leading to some physicochemical, sensorial, functional and nutritional quality losses. The dehydrated leeks showed a high color change particularly due to degradation of heat-sensitive colour compounds in addition to the browning reactions and pigment destruction. Fresh and dried leek samples exhibited antioxidant activity. However, the antioxidant capacity decreased by more than $50 \%$ in the dried leek samples. Fresh leeks had a much higher phenolic content as compared to the dehydrated leeks, which was mainly due to the breakdown of phenolics during dehydration.

\section{References}

Anese M, Manzocco L, Nicoli MC, Lerici CR (1999). Antioxidant properties of tomato juice as affected by heating. J Agri Food Chem 79:750-754.

Anonymous (2008). Undersecretariat of the Prime Ministry for Foreign Trade. Export Promotion Center of Turkey. Dried Vegetables Report No:056.1. p. 5.

AOAC (2000). Official Methods of Analysis. Association of Official Analytical Chemists, Washington, DC, USA.

AOAC (1996). Association of Official Analytical Chemists Official Methods of Analysis. Washington, DC, USA.

Araujo EAF, Ribeiro SCA, Azoubel PM, Murr FEX (2004). Drying kinetics of nectarine (Prunus persica) with and without shrinkage, p. 2189-2194. In: Proceedings of the $14^{\text {th }}$ International Drying Symposium, Vol. C, São Paulo, Brazil.

Attanasio G, Cianquanta L, Matteo MD (2004). Effect of drying temperature on physico-chemical properties of dried and rehydrated chestnuts (Castanea sativa). Food Chem 88:583-590.

Benzie IFF, Strain JJ (1999). Ferric reducing antioxidant power assay: Direct measure of total antioxidant function of biological fluids and modified version for simultaneous measurement of total antioxidant power and ascorbic acid concentration. Methods Enzymol 299:15-27.

BianchiniF, Vainio H (2001). Alliumvegetablesand organosulfur compounds: do they help prevent cancer? Environ Health Perspect 109:893-902.

Butz P, Edenharder R, Fernandez Garcia A, Fister H, Merkel C, Tauscher B (2002). Changes in functional properties of vegetables induced by high pressure treatment. Food Res Int 35:295-300.
Cao G, Sofic E, Prior RL (1996). Antioxidant activity of tea and common vegetables. J Agri Food Chem 44:3426-3431.

Cohen JS, Yang TCS (1995). Progress in food dehydration. Trends Food Sci Tech 6:20-25.

Crozier A, Lean MEJ, Mc Donald MS, Black C (1997). Quantitative analysis of the flavonoid content of commercial tomatoes, onions, lettuce and celery. J Agri Food Chem 45:590-595.

Dewanto V, Wu X, Adom KK, Liu RH (2002). Thermal processing enhances the nutritional value of tomatoes by increasing total antioxidant activity. J Agri Food Chem 50:3010-3014.

Di Scala K, Crapiste G (2008). Drying kinetics and quality changes during drying of red pepper. LWT-Food Sci Tech 41:789-795.

Doymaz I (2008). Drying of leek slices using heated air. J Food Process Eng 31:721-737.

Erdman WJ, Klein PB (1982). Harvesting, processing and cooking Influenceson vitamin $\mathrm{C}$ in foods, p. 499-532. In: Seib PA, Tolbert BM (Eds.). Ascorbic Acid: Chemistry, Metabolism and Uses. American Chemical Society, Washington D.C.

Fattorusso E, Lanzotti V, Taglialatela-Scafati O, Cicala C (2001). The flavonoids of leek, Allium porrum. Phytochem 57:565-569.

Ferary S, Auger J (1996). What is the true odour of cut Allium? Complementarity of various hyphenated methods: gas chromatography-mass spectrometry and high-performance liquid chromatography-mass spectrometry with particle beam and atmospheric pressure ionization interfaces in sulphenic acids rearrangement components discrimination. J Chromatogr A 750:63-74.

Galeone C, Pelucchi C, Levi F, Negri E, Fraceschi S, Talamini R, Giacosa A, La Vecchia C (2006). Onion and garlic use and human cancer. Am J Clin Nutr 84:1027-1032.

Giovannucci E, Willet WC, Stampfer MJ, Liu Y, Rimm EB (2002). A prospective study of tomato products, lycopene, and prostate cancer risk. J Natl Cancer Inst 94:391-396.

Hawlader MNA, Perera CO, Tian M, Yeo KL (2006). Drying of guava and papaya: impact of different drying methods. Dry Technol 24:77-87.

Heinonen MI, Ollilainen V, Linkola EK, Varo PT, Koivistoinen PE (1989). Carotenoids in Finnish foods: Vegetables, fruits, and berries. J Agri Food Chem 37:655-659.

Hsing AW, Chokkalingam AP, Gao YT, Madigan MP, Deng J, Gridley G, Fraumeni JF (2002). Allium vegetables and risk of prostate cancer: a population based study. J Natl Cancer Inst 94:1648-1651.

Jayaraman KS, Gupta DKD (1995). Drying of fruits and vegetables, 669 p. In: Mujumdar AS (Ed.). Handbook of industrial drying. New York: Marcel Dekker, Inc.

Kevers C, Falkowski M, Tabart J, Defraigne JO, Dommes J, (2007). Evolution of antioxidant capacity during storage of 
150 selected fruits and vegetables. J Agri Food Chem 55:85968603.

Koca N, Burdurlu HS, Karadeniz F (2007). Kinetics of colour changes in dehydrated carrots. J Food Eng 78:449-455.

Konings EJM, Roomans HHS (1997). Evaluation and validation of an LC method fort he analysis of carotenoids in vegetables and fruit. Food Chem 59:599-603.

Lanzotti V (2006). The analysis of onion and garlic. J Chromatogr A 1112:3-22.

Latapi G, Barrett M (2006). Influence of pre-drying treatments on quality and safety of sun-dried tomatoes. Part I: Use of steam blanching, boiling brine blanching, and dips in salt or sodium metabisulfite. J Food Sci 71:24-31.

Luangmalawat P, Prachayawarakorn S, Nathakaranakule A, Soponronnarit S (2008). Effect of temperature on drying characteristics and quality of cooked rice. LWT-Food Sci Tech 41:716-723.

Magra TI, Bloukas JG, Fista GA (2006). Effect of frozen and dried leek on processing and quality characteristics of Greek traditional sausages. Meat Sci 72:280-287.

Maharaj V, Sankat CK (1996). Quality changes in dehydrated dasheen leaves:effect of blanching pre-treatments and drying conditions. Food Res Int 29:563-568.

Maskan M, Kaya C, Maskan M (2002). Hot air and sun drying of grape leather (pestil). J Food Eng 54:81-88.

Matos HR, Capelozzi VL, Gomes OF, Di Mascio PD, Mederios MHG (2001). Lycopene inhibits DNA damage and liver necrosis in rats treated with ferric nitrilotriacetate. Arch Biochem Biophys 396:171-177.

Meyer AS, Donovan JL, Pearson DA, Waterhouse AL, Frankel EN (1998). Fruit hydroxycinnamic acids inhibit human low-density lipoprotein oxidation in vitro. J Agric Food Chem 46:1783-1787.

Mondy N, Duplat D, Christides JP, Arnault I, Auger J (2002). Aroma analysis of fresh and preserved onions and leek by dual solidphase microextraction-liquid extraction and gas chromatographymass spectrometry. J Chromatogr A 963:89-93.

Moser U, Bendich A (1991). Vitamin C, p. 195-232. In: Machlin LJ (Ed.). Handbook of vitamins. Marcel Dekker, New York.

Nicoli MC, Anese M, Parpinel MT, Franceschi S, Lerici CR (1997). Study on loss and/or formation of antioxidants in food during processing and storage. Cancer Lett 11:71-74.

Nindo CI, Sun T, Wang SW, Tang J, Powers JR (2003). Evaluation of drying technologies for retention of physical quality and antioxidants in asparagus. LWT-Food Sci Tech 36:507-516.

Okos MR, Narsimhan G, Singh RK, Witnauer AC (1992). Food dehydration. In: Heldman DR, Lund DB (Eds.). Handbook of Food Engineering, Marcel Dekker, New York.

Ottaway PB (1993). Stability of vitamins in Food, p.90-113. In: Ottaway PB (Ed.). The technology of vitamins in food.
Chapman and Hall, Cornwell.

Prothon F, Ahrne LM, Funebo T, Kidman S, Langton M, Sjoholm I (2001). Effects of combined osmotic and microwave dehydration of apple on texture, microstructure and rehydration characteristics. LWT-Food Sci Tech 34:95101.

Raghavan GSV, Orsat V (2007). Recent advances in drying of biomaterials for superior quality bioproducts. Asia-Pacific J Chem Eng 2:20-29.

Rangana S (1986). Handbook of analysis and quality control for fruit and vegetable products. Mc Graw Hill, New Dehli, p. 976-979.

Senadeera W, Bhandari B, Young G, Wijesinghe B (2000). Physical property changes of fruits and vegetables during hot air drying, p. 149-162. In: Mujumdar AS (Ed.). Drying Technology in Agricultural and Food Sciences Science Publishers, Enfield, USA.

Shi J, Le Maguer M, Kakuda Y, Liptay A, Niekamp F (1999). Lycopene degradation and isomerization in tomato dehydration. Food Res Int 32:15-21.

Sigge GO, Hansmann CF, Joubert E (2001). Effect of storage conditions, packaging material and metabisulfite treatment on the colour of dehydrated green bell peppers (Capsicum annuum L.). J Food Quality 24:205-218.

Singh S, Raina CS, Bawa AS, Saxena DC (2006). Effect of pretreatments on drying and rehydration kinetics and color of sweet potato slices. Dry Technol 24:1487-1494.

Sobukola OP, Dairo OU, Sanni LO, Odunewu AV, Fadiolu BO (2007). Thin layer drying process of some leafy vegetables under open sun. Food Sci Tech Int 13:35-40.

Spanos GA, Wrolstad RE (1990). Influence of processing and storage on the phenolic composition of Thompson seedless grape juice. J Agri Food Chem 38:1565-1571.

Steinmetz AK, Potter DJ (1996). Vegetables, fruit, and cancer prevention: A review. J Am Diet Assoc 96:1027-1039.

Stewart AJ, Bozonnet S, Mullen W, Jenkins GI, Michael EJ, Crozier A (2000). Occurrence of flavonols in tomatoes and tomato-based products. J Agri Food Chem 48:2663-2669.

Taiwo KA, Angersbach A, Knorr D (2002). Influence of high electric field pulses and osmotic dehydration on the rehydration characteristics of apple slices at different temperatures. J Food Eng 52:185-192.

Takeoka GR, Dao L, Flessa S, Gillespie DM, Jewell WT, Huebner B, Bertow D, Ebeler SE (2001). Processing effects on lycopene content and antioxidant activity of tomatoes. Int J Food Sci Nutr 56:597-605.

Toor RK, Savage GP, Lister CE (2005). Antioxidant activities of New Zealand grown tomatoes. Int J Food Sci Nutr 56:597605.

Tsouvaltzis P, Gerasopoulos D, Siomos AS (2006). Effect of storage temperature and size of stalks on quality of minimally processed leeks. J Sci Food Agri 86:372-379.

Vega-Gálvez A, Uribe E, Lemus-Mondaca R, Miranda M (2007). 
Hot-air drying characteristics of Aloe vera (Aloe barbadensis Miller) and influence of temperature on kinetic parameters. LWT-Food Sci Tech 40:1698-1707.

Vega-Gálvez A, Lemus-Mondaca R, Bilbao-Sainz C, Fito P, Andres A (2008). Effect of air drying temperature on the quality of rehydrated dried red bell pepper (Capsicum annuum L.). J Food Eng 85:42-50.

Vega-Gálvez A, Di Scala K, Rodríguez K, Lemus-Mondaca R, Miranda M, López J, Perez-Won M (2009). Effects of air-drying temperature on physico-chemical properties, antioxidant capacity and total phenolic content of red pepper (Capsicum annuum L. var. Hungarian). Food Chem 117:647-653.

Velioglu YS, Mazza G, Gao L, Oomah BD (1998). Antioxidant activity and total phenolics in selected fruits, vegetables and grain products. J Agri Food Chem 46:4113-4117.

Vergawen R, Van Leuven F, Van Laere A (1998). Purification
151

and characterization of strongly chitin-binding chitinases from salicylic acid-treated leek (Allium porrum). Physiol Plant 104:175-182.

Villota R, Hawkes JG (1992). Reaction kinetics in Food systems, p. 39-144. In: Heldman DR, Lund DB (Eds.). Handbook of food engineering. Marcel Dekker, New York.

Wellburn AR (1994). The spectral determination of chlorophyll a and chlorophyll b as well as total carotenoids, using various solvents with spectrophotometers of different resolution. J Plant Physiol 144:307-313.

Yin MC, Tsao SM (1999). Inhibitory effect of seven Allium plants upon three Aspergillus species. Int J Micro 49:49-56.

Zanoni B, Peri C, Nani R, Lavelli V (1999). Oxidative heat damage of tomato halves as affected by drying. Food Res Int 31:395-401. 